\title{
Exploring the Different Roles and Aspects of Music
}

\author{
Ramesh Pokharel, PhD*
}

\begin{abstract}
This paper explores different roles and aspects of music, describes its value, power and essential role in our daily life. The main objective of this article is to highlight the overall musical power in different aspects. Music affects both our body and mind. So, whenever we get time, we listen to Music. This makes us feel fresh even in old age. Music provides exercises to the mind. This is the reason why music is being used as therapy in hospitals even today. It has been seen that patients who listen to music take less time to improve. There are different genres of music like classical, semi-classical, light, folk, and their varieties of compositions with a magical quality, which we can enjoy according to our needs and requirements. Musical composition plays a vibrant part in everybody's normal life. It keeps us busy in free time. The rationalized sound, which arises from the creation of aesthetic-rasa, is called music. In eastern philosophy, Nada-Brahma (sacred-sound) is the primary source of music. This sound is called AUM, in which the whole universe remains vibrant. The impact of music on the living world is not hidden from anyone. Music is also the best way to practice yoga and meditation because it improves physical and mental health. It can be used for a therapeutic purpose too. It gives us peace in our challenging times and further enhances our happiness in good times. We can always use it to be happy. It is also beneficial for all professionals in different fields of society.
\end{abstract}

Keywords: aesthetic value, social value, therapeutic power, spiritual power, harmony, professional importance

\section{Methods and Materials}

The main objective of this paper is to highlight about the impact of music in our daily life. Overall power, value, and importance of music are analyzed with a qualitative approach. This is a descriptive and analytical study based on secondary sources of information. Relevant books, articles, journals, websites, research reports are sources of the study.

${ }^{*}$ Dr Pokharel is Associate Professor and currecntly working as the Campus Chief of Fine Arts Campus, Tribhuvan University, Nepal. 


\section{Introduction}

Being the common language of the emotion of artistic souls, music cannot be confined in a limited geographical boundary though it is diverse from place to place, civilization to civilization, and present-generation to coming-generation. For centuries the people of the Indian sub-continent have always been seekers of truth, mysteries, and nature. Music in this south Asia is supposed to be single of the eldest continuous civilizations which go back to the Vedas. Many famous legends have grown up concerning the origins and development of classical music on the continent. Music is an influential and powerful medium that delivers a very lively message to everyone. The mother nature of music is also to encourage and promote the power of human concentration by removing all harmful thoughts and negative vibes, and its touchy quality helps us to revive all the decent memories (Sambamoorthy, 1958). The language, contents, and styles of music of different countries or society may diverge. Still, it has always been used as a source of entertainment, cultural and religious practices, and for practical and artistic communication all over the world."Concentrating our attention on the content of the sound would expose to us how music is knitted with musical sound-pitch with its dynamic movements through ascending and descending notes and scales. This lifts our mind with aesthetic appeal wherever it drives, while its rhythms unconsciously make us respond to its bends and turns making us nod our head and move the body and limbs"(Sairam, 2004).

During the 20th and the beginning of $21^{\text {st }}$ century, the development of the automated open multimedia converted entree to music. We twisted on the radiotransistor, tape-recorder, Television-broadcast, CD-disc to various public sites and multi-media with easy access. Due to the integral part of our everyday lives, music is being consumed in a big way by individuals and societies in recent days, which would have been much more challenging in previous days. There was no any social sites and multimedia like today, to divert one's mind. Music used to help individual with monotonous lifestyles for the better connection with each other in those days. With the developing trend of our society, people gradually started to play instrumental percussion and sang various genres of folk, classical, and light songs with lively dancing to their tunes for the entertainment. In this way music became an integral part of our daily rite and ritual practice that run from our birth to funeral process (Gag, 1999).

Music is a great choice for people who are disheartened, feeling unhappy, and depressed. It has diverse components like bringing together, harmony, speed-beats, regularity, tone, melody, phrases, texture and grace, allocation of voices, dynamics, expression, appearance, communications, form, and structure. There are many things in music in which one can listen and pay attention. Music can make them feel happy, stress less, tension-free, calm, and delightful. 
Music has such a power which can change our temperament in just a few seconds. Whenever we listen to some musical genre or any compositions, we can immediately enjoy it, and sometimes our mood even starts to dance in its rhythm. This is not fair to say, all types of musical genre can make us lively. It depends on the kind of music which we are listening to. But if someone comes and quickly changed the music track of the played song and sets some sad emotional song, our mood deviates at a time. We immediately start to sense the emotions which are hidden in the music compositions. That's why we should hear such pieces that cheer us up when we feel near to the ground. When we feel hopeless or unhappy, we should listen to the music, full of liveliness, not very gloomy or sensitive. While some lousy memory is disappointing us, it is one of the best options to forget that memory, at least for the time being (Fletcher, 2001).

\section{Power}

If there is one thing that continuously exists in this world, it is the power of music. It raises our frame of mind, cuts pressure, and improves our overall health. A good melody is one of the gifts of God to men. It enhances the mind and emotions and lifts the soul through the melodic and harmonious organization of sound patterns. This is the supreme one among all genres of fine arts. Sambamoorthy states that while for all other fine arts, nature provides man with great ideas; the structure of music was advanced by the brilliance of man himself. He emphasizes that music is one of the most natural and normal of entire arts (Sambamoorthy, 1958, p.1-2). Music has a collective charm to win over all levels of age group, gender, communal status, schooling, and teaching levels. It is our first-born form of communication and expression, more mature than verbal or fine arts. It originates in the vocal sound and has tremendous requirement to touch others. That connects our spirits more powerfully than verses. The existence of music will be essential so far the human race survives. It is our primary need (Yahudi and Curtis, 1979, p. 1). Even the creatures respond to music. It is said that cows reacted to Krishna's flute and the snakes feel the charm of piece if the eastern classical raga is played. Recent scientific studies have shown that flowers grow faster, and farmers harvest more prosperous crops, and cows produce more milk if music is played.

Remedial treatment of Music is one of the best ways of controlling emotions, hypertension, and regenerating the working of the different organs of the body. It has been used by a psychiatrist, therapist, mediator, and peacemaker. Most of our every work starts with music in diverse ways to complete numerous goals. As reported by Bancroft (1985), vocal and instrumental Music can be used for therapeutic purposes rather than beauty or aesthetics. The communicative quality of music can be both a pleasant and therapeutic experience. For music therapy, it is crucial to vibrate the cells 
of the mind and body. Through these pulsations and vibrations, unhealthy being's consciousness can be transformed successfully to encourage health.

Music researches, science, and medicine are re-experiencing the therapeutic powers of music in recent days. Musical beat stimulates the pituitary gland, whose secretions affect the nervous system and blood circulation. Melodious music helps a person relax, refresh, and calm himself. Even during working, mostly the raga based classical, light, and traditional folk genres of music improve efficiency. Difficulty, obstacles, unfairness, and frustration can be controlled by listening to a piece of good music. At rehabilitation centers, therapy has been used by musical practice forages, helping people to survive with their unrecovered pain, manage stress, and improve memory (Kalyan, 2002). Some researchers state that when patients started listen to a melodious music during their surgery, earlier or later, they felt less pain and hurt. In the concentrations of people, musical rhythm, melody and lyrics make a place worth living in many ways. Music has effect on everyone's life, from humans to plants, flowers, birds, animals, etc. Researchers have proved that the cure of diseases can be done well through music. Its usage has been very successful in the treating of lung, throat, eye disease, and heart disease.

The emotional appeal of music transfers to the mental and physiological dimensions, leading to its curative and therapeutic effect. It is said that specific classical ragas are capable of curing sicknesses. Music remedy was known not only in ancient times but even today. Some doctors use it to relieve pain during particular painful treatments and help the patients towards a speedy recovery. Thus, aesthetic could serve the same purpose as an anesthetic in eliminating pain realization, but without having any contrary effect on the speed of recovery.

It is claimed that even the heart is bound to react kindheartedly to music. While singing, the human voice gets trained, the tissues of the body also vibrate, and are kept alive. When we listen to good music, the subtle threads in the inner ear respond. Thus, they become very active. Both vocal and instrumental Music keep the nervous system perfect. The power of music to change the sensitive makeup of human beings has been acknowledged. In prisons, music has been improved to calm down uncontrollable prisoners. In some educational institutions, provocative classes have been improved through music. In this sense Music has great power to change the temperament in human beings.

\section{Spiritual Power}

The knowledge of Nada-Brahma (sacred sound) is an essential branch of the Eastern school of spirituality. There is no mantra superior or more significant than AUM or OM (supreme sound). That sound, when recited even once, uplifts spiritually. 
While reciting AUM, we generate inside a sensitive trembling within our body, and for the moment we stand in harmony with the universe. Weperform AUM, as well as generate a musical quivering in our physical and spiritual coordination (Krishnananda, 1996, P. 61). "All God's creatures are the spirit of nada. Not any songs, musical notes, dance minus nada, therefore Pt. Saarangadev, a great sage and writer of Sangeet Ratnakar in13th century, stresses that nada-sound is the identical soul of singing. Instrumental music is pleasurable, as it expresses nada. Nritta-dance associates together hence altogether be governed by supreme nada"(Sharma and Shringy, 1978, pp. 21-23).

In the early days of human civilization, people habituated to perform their feelings through different types of tunes and movements of the body. Later on, in the Vedic period, music acquired some form. The saints of that time used to sing the hymns of the Vedas in a musical chant. Apart from this, theme was familiar in different sacrificial ceremonies of the Aryans. Hymns from Sama-Veda were sung at those functions. The use of music was, however, limited to performances at sacred places only (Khan, 1992, p.12).

Since ancient times, music in this continent has been practiced as a spiritual science and art, a means to enlightenment and self-interview. The proper practice and Upasana (worship) of Nada-Brahma complete the communication cycle by bringing divine messages and motivations to the Sadhaka (entirely devoted person) by the realizing of the subtle sounds -Anahata Nada in the inner self.

As stated in Vedic-literature, music created from Nada, which is the atmosphere or ether. Under the musical nada, we found two types of sound, the Aahat nada or struck sound is audible, whereas the Anahata nada or unstruck sound is inaudible. Vedic sages believed that the evolution of the Brahmand or Universe was caused as a result of atomic explosion that produced infinite waves of sound, which represent cosmic ascent and expansion. The sound was a monosyllable: OM. Since OM is related to the beginning of the universe, Hindus consider it the most sacred syllable with which Vedic mantras originated. The AUM is the origin of both Shabda-Brhma (verbal-sound) and Nada-Brahma, and both are interlinked (RgVeda.html).

Music was a part of religious rituals in ancient India. Music and incantation were needed details of Yagya (fire sacrifices) and other spiritual practices. In those days notable singers used to sing at the sacrifices to the veena's accompaniment (Ramakrishna, 2003, p.1). Later on, this form of music took the shape of classical music in South Asia. Classical music of Indian sub-continent is usually severe and devotional based on Ragas following long-established principles. It is phrase of spiritual aesthetics. It is a means of self-realization and salvation of the soul rather than a simple expression (Chakravarty, 1999, p.68). 
The Yajurveda recitation was more rhythmic than the incantation of Sama-Vedic melody. (Rama Krishna, 2003, p.15). The initial formal music was the Sama-Vedic music developed by folk music. Gandharva music was the emerging form, as mentioned in sage Bharata's Natyashastra. Sam-Vedic scales, murchhna (tonal frames by origination ascents and descents, ranging over seven notes) Gram (initial music scales), which shaped different sort of melodicstructurenamed Jaati (tonal organization). Vedic music was the initial form of today's classical music and other music genres. People of South Asia and abroad have very much respect for this spiritual music genre.

\section{Value}

Without the knowledge of music, a person cannot be said to be completely human. It can be measured as one of the basic needs of a man. Music education helps a child to develop his native talents to the complete range, to improve his life and develop self-confidence in his abilities. It draws out diverse human talents from within the mind and the spirit.

South Asia is an open arts center of the great heritage of different fine arts genres like painting, sculptor, music, dance and drama, etc. The diverse cultural heritage is unified by the common identification of expression of art. Many musical genres have been used in this sub-continent as a worship tradition for a long and to express mythological stories and transmit traditional uniqueness. Fine art is a mirror of society. Various branches of painting, music, literature, dance, and other creative activities are included in art. Music has a major influence on religious conviction, civilization, and schooling. Music including other art forms e.g. painting, literature, dance and drama reflects the current state in the society. Among all fine arts forms, music has several kinds of aesthetic, collective, entertaining, therapeutic, creative, spiritual, artistic, and it shows music appealing values.

Music has a social and economic aspect too. One of the most valuable social dimensions of music is that people of fluctuating talents and backgrounds can join together. This is not only being achieved in the socialistic nations and the western countries today, but even in the caste scattered South Asian society. Musician-sages have always tried to bridge the gulf amongst people through the use of music compositions and melody.

Music is a significant economic creator of income in most advanced society and nations engaging hundreds of individuals in musical activities whereby musicians can earn money and improve the quality of life. Besides the performance, this needs a supply of artists for their economic sustainability with the requirement of extraordinary music experts and professionals. 
Music is an extremely sensitive concept, and it depends on our mood and atmosphere. It is not only activity, enjoyment, entertainment, and extra-curricular activities of any school or college but an art that gives immeasurable joy to the mind and heart of the people. It has a rich heritage that has come to us from time immemorial. It is not only a pastime or amusement but an art that gives infinite joy to the mind and the heart. Music develops a sense of beauty in a person and contributes to their cultural refinement. The country which abounds with many musicians and their unique art can be rich and prosperous.

\section{Importance}

Music is like yoga. It makes us happy and also sustains hormonal balance in our bodies. It helps us to keep our body fit both physically and spiritually. It also works to care for us from mental problems.

Music suddenly touches our heart, mood, makes us enthusiastic, quiet, and happy. Every human being can get delighted in performing, listening, humming, dancing, and drumming percussion. Even though this is a common widespread interest, various educational institutions have been compelled to go out of their music teaching and learning activities. It is an injustice. It is not fair to stop them with their natural rights. Not only for the schools, but it is a significant loss of our society. Music education can heighten schoolchildren being in this world with their creativity. The aim of teaching music in schools should be to help the children to express their feelings freely, thoughts, and ideas through music. Music is suitable for their memory (Yahudi and Curtis, 1979, p. 40). From the perspective of cultural and religious value, music has been used as a good medium of communication and education. "A well-established music industry and its related educational institutions help a nation prosper artistically, aesthetically, socially, culturally, and economically creating huge opportunities for the jobs of different professionals related to this field"(http://hdl.handle.net/10603/268334, p.1).

Music helps us clarify our thoughts, ideas, spirits, and creativity. The development of creative power in an individual merits his attention. Music initiates wherever people have feelings that they wish to express or share with others. Improvement of presentation skills helps the individual become more skillful in conveying his thoughts, moods, or concepts. One learns to communicate by giving natural release to one's feelings and ideas - by actually using one's own creative powers. An expression of music is an actual physical process like how light and heat influence nature and the living world. This makes their body grow healthy. In the same way, music also has thermic and internal energy and it holds such an essential place in the development of human beings. 


\section{Conclusion}

Music is a language by itself, capable of expressing refined thoughts. The impact of music on the living world is not hidden from anyone. It plays a significant role in our daily lives. There are various genres of music practices worldwide, which we can enjoy according to our needs and requirements. Music helps to practice yoga and meditation because it improves both physical and mental health. In a creative, innovative, and imaginary way, it grows our concentration, mood and gives us immeasurable peace, happiness, and spiritual feelings. Among all fine arts forms, music has several kinds of aesthetic, collective, entertaining, therapeutic, creative, spiritual, artistic, and its own musical appealing values. A good music grows our intelligence and skills. It is essential for our kids to enhance their creativity while teaching them. The emotional appeal of music transfers to the mental and physiological dimensions leading to its therapeutic effect. It is said that a particular musical genre of eastern music is capable of curing some diseases. In music therapy, doctors use it to relieve pain during specific painful treatments and help the patients towards a speedy recovery.

The knowledge of Nada-Brahma is an important branch of the Eastern school of philosophy. There is no hymn superior to AUM. That sacred sound, when recited even once uplifts spiritually. While reciting AUM, we generate inside a sensitive vibration within our body and at a time, we stand in harmony with the Universe. Nada-sound is the primary source of all the genres of music.

Music is an international language too. It has no barriers of religion, race, caste, class, faith, or philosophy. When music comes to be practiced, this world will be a cheerier place to live. The study and practice of music give taste, grace, attraction, gentleness, and fine-tuning to the person. It develops the creamy qualities of human kindness and sympathy. A composer expresses his ideas through the medium of musical sounds. The monotonous, uninteresting and routine character of life is considerably relieved by listening to a beautiful music. It is a common mother-tongue of humanity. It is a great unifying force. Music is the foundation of many arts and institutes an integral part of a nation's prosperity. Many music philosophers and scholars of the world have stressed the various aspects of power, value and significance of music through their different experiments and perception. Our worldwide musicians and composer's opinions are very lively towards the importance and supremacy of music and its spirituality too.

\section{References}

Bancroft, W. J. (1985). Music therapy and education. Journal of the Society for Accelerative Learning and teaching, Vol. 10, No. 1, pp. 3-19, (ERIC Document Reproduction No. ED 285 414). 
Chakravarti, I. (1994). Music: Its methods and techniques for teaching in higher education. New Delhi: Mittal Publications.

Fletcher, P. (2001). World Music in Context: A Comprehensive Survey of the World's Major Musical cultures. New York: Oxford University Press, Inc.

Garg, B. (1999). Sangeetvisharad (23rd ed.). Hathras, India: Sangeetkaryalaya Hathras.

Kalyan, B. (2002). Music therapy as an A alternative medicine. New Delhi: An Alternative Medicine' Society for Erotological Research.

Khan, M. H. (1992). Islamic contribution to South Asia's Classical Music. New Delhi: Sterling Publishers Private Limited.

Krishnananda, S. (1996). The Mandukya Upanishad. Rishikesh: The Divine Life Society Sivananda Ashram.

Majumdar, R. C. (1968). The History and the culture of the Indian People: The Age of Imperial Unity (4 ed. Vol. 2). Bombay: BharatiyaVidyaBhavan.

Ramakrishna, L. (2003). Musical Heritage of India. New Delhi: Shubhi Publication. Sairam, T.V. (2004). What is music? Chennai: Nada Center for Music Therapy Sambamoorthy, P. (1958). South Indian Music. (Book-I). Madras: The Indian Music Publishing House.

Sharma, P. L. \& Shringy, R. K. (1978). Sangitaratnakar of Sarangdeva (Reprint Vol. I). Delhi: Motilal Banarsidass. Pp. 21-23

Singh, T. J. (1995). Indian Music. Calcutta: Sangeet Reasearch Academy.

Yehudi, M. and Curtis, W. D. (1979). The Quiver of life, The Music of Man. London: Macdonald General Books.

http://hdl.handle.net/10603/88881

https://www.azquotes.com/quote/1358537?ref=power-of-music

https://everydaypower.com/music-quotes/

https://medium.com/the-musicpreneur/what-is-the-value-of-music-22439ee745d5 https://www.mitchdeklein.com/blog/201688-reasons-why-music-is-important-to-us https://www.gilbertgalindo.com/importanceofmusic

https://targetstudy.com/articles/importance-of-music-in-human-life.html http://hdl.handle.net/10603/292103 https://ayurveda-foryou.com/music/music.html http://hdl.handle.net/10603/268334 https://www.valdostamuseum.com/hamsmith/RgVeda.html 